\title{
Editorial
}

\section{The Iron Brand: Margaret Thatcher and public diplomacy}

Place Branding and Public Diplomacy (2013) 9, 67-70. doi:10.1057/pb.2013.9

They are known as illumination rounds: artillery shells designed to burst $600 \mathrm{~m}$ or so above a battlefield and bathe a square kilometre of nighttime terrain in light. For a few seconds the positions of friends and foes and the technologies in play on the field are rendered visible. The battle is known. Unexpected events can act in this way for nations. A news story breaks and observers have an instant picture of the state of attitudes within a society and the methods used to communicate at that moment in time. The death of former British Prime Minister Margaret Thatcher was such a moment for the United Kingdom. In a few spring days in 2013 the attitudes of British society around a cluster of political issues from privatization and the fate of the welfare state to shifts in national identity were thrown into relief and, no less intriguingly, the methods by which the news and associated debate spread carried their own message. The news travelled across a hybrid mesh of electronic, social and 'legacy' print and broadcast channels. Britons around the world toggled between Facebook and favoured news sites, sharing the editorials, commentaries, blogs and tweets, which fitted their own take on the death of someone who - whatever their political stripe - was central to a decade of their lives and had considerable influence further afield. One corner of the field illuminated by the death of Margaret Thatcher is our own area of place branding and public diplomacy (PD).
The first point to make is that Margaret Thatcher's tenure as Prime Minister was a milestone in the evolution of political communication in Britain. Unlike her predecessors, she was closely tutored to make the best of the medium of television. She worked closely with leading lights in the British advertising industry to develop a string of potent messages for the 1979 general election. Her press secretary was an essential member of her political team. Her advisers believed it was necessary to control messages and this was never as clear as during the 1982 Falklands/Malvinas war during which the British government was able to strictly limit reporting of the war and, thereby established a model of media control. Other governments emulating the model included the United States in its operations in Grenada, Panama and the first Gulf War. Thatcher's government worked equally hard to control the messages around the conflict in Northern Ireland. Thatcher understood terrorism as a form of communication and (borrowing a metaphor from the Chief Rabbi of the day) spoke of the need to deny the terrorist the 'oxygen of publicity'. This insight was crudely applied and resulted in heavy handed treatment of the British media prompting at one point a journalist strike at the British Broadcasting Corporation (BBC) and later a broadcasting ban that forbade the transmission of the actual voices of terrorists on British airwaves. News organizations were obliged to get 
round the obstacle by hiring actors to provide the voices of paramilitary spokesmen from Northern Ireland. It was an awkward foundation for the international component of her messaging.

Margaret Thatcher was her own central contribution to British PD. As her admirers are swift to point out, she was a powerful voice for Britain. Her famous tag of 'Iron Lady' was in itself a testament to her international impact, being generated by a Soviet military newspaper in January 1976 in response to a confrontational speech as leader of the opposition a few days earlier. She immediately embraced the soubriquet as a badge of honour. ${ }^{1}$ The content of her personal-public diplomacy was not always welcome, most especially on the mainland of Europe where she rained on the gathering parade of European integrators and seemed callous in her response to the Provisional Irish Republican Army (IRA) hunger strike in 1981. Yet, she made a vigorous and consistent claim to the significance of her country in world affairs. As Simon Anholt (editor emeritus of this journal) has put it she, like Churchill before her and Blair after her, 'paid the rent' on the UK's international profile. British politics seems particularly responsive to a certain collision of idiosyncrasy and eloquence in its leaders, which does not emerge as readily from its neighbours and serves to boost the UK's image. For some groups around the world her own take on this role had particular significance. As a British person travelling abroad in the 1990s, it was humbling to realize that my personal (negative) response to Margaret Thatcher had to be set against the significance she held for the newly democratic countries of Eastern Europe. I well remember the enthusiasm with which my hosts at a conference in Hungary in 1996 took me see the central market hall in Budapest where Margaret Thatcher had purchased a bunch of garlic during a post-change visit in September 1990. For them and other Eastern Europeans Thatcher was an implacable voice for their freedom and an essential element in the final phase of western PD's ideological assault on the
Communist Bloc. Her rhetorical legacy in the other great democratic battles of the era is less clear. South Americans recall her support for the Pinochet regime in Chile. South Africans remember her opposition to the application of sanctions against the Apartheid regime and jibes against the 'terrorists' of the African National Congress. $^{2}$

Her wider contribution to the routine application British PD with its day-to-day habits of advocacy, exchanges, broadcasting, cultural work and, above all, listening to foreign opinion is mixed. Although Margaret Thatcher's American analogue, Ronald Reagan ushered in something of a Golden Age in American PD, expanding the budget for international engagement; boosting exchanges, modernizing Voice of America and launching multiple initiatives to promote democracy, the same cannot be said of Thatcher. The Foreign Office launched its Chevening Scholarship programme on her watch (1983) but there were few other major initiatives of note. The Westminster Foundation For Democracy, which built on Thatcher's commitment to democratization around the world, did not appear until 1993. Other elements in Britain's PD line-up remember the 1980s as an era of soldiering on rather than prosperity. The British Council - like so many recipients of British taxpayer money - spent a decade scrambling for resources. Its achievement was to make a convincing case within Whitehall that PD contributed to the UK's export drive - a claim that helped it to avoid being knocked back by the disappearance of the Cold War rationale for PD in the 1990s. The loss of that rationale, in contrast, did so much to damage US work at that time. The BBC World Service was sucked into the Thatcher government's budget cuts and its running battle with the BBC. The archives of the Jimmy Carter White House include an appeal from the BBC via the US embassy in London for the United States to intervene to beg the new Prime Minister Thatcher not to cut the World Service budget by 30 per cent. ${ }^{3}$ There were some backward steps in the fields of dialogue and cultural 
exchange. The Thatcher period saw Britain's withdrawal from UNESCO in protest against alleged mismanagement of the international organization. It was a low point in the UK's international cultural relations.

The elements of British PD served as multipliers in Thatcher's defiance of Soviet hegemony in Easter Europe. Star turns included the BBC Russian service's resident DJ Seva Novgorodtsev. Other notable PD campaigns in the era included that directed at the United States to contest the negative publicity around the Northern Ireland conflict. Tactics included upgrading the press relations apparatus originally established in the Second World War to ensure that the major consulates across the United States had resident experts on Northern Ireland. These spokesmen were regularly rotated through visits to the province and were hence equipped with the authority of recent first-hand experience when confronted by Americans who wished to opine on the situation. In concert with this advocacy campaign, the Thatcher government channelled a flood of material unrelated to Northern Ireland across the Atlantic - making excellent use of the new British Council office in Washington DC, royal visits and the blockbuster show 'Treasure Houses of Britain', which displayed masterpieces from British country houses. The effort succeeded in preventing Britain being branded by the troubles. In retrospect such success was probably a mixed blessing - the equivalent of hiring a master carpenter to fit a beautiful piece of teak dashboard over flashing warning lights in one's car. Britain might have done better to have listened to the international concern over the troubles rather than drowning it out. PD success merely delayed the day when the United Kingdom had to sit down with terrorists and extremists on both sides of the conflict and drew forth a further round of violence to keep the issues alive in the interim.

Although the Thatcher period did not produce a revolution in the government's external representation of Britain, it is possible to see the rise of the 1990s concepts of the place brand and the Blair-era interest in
Britain's image as an extension of the Thatcher era. The 'New' Labour Party of Tony Blair with its own fixations on the power and priority of images had learned much from the Thatcher approach. Without the Thatcher experience it is difficult to imagine Britain taking the lead in the applications of place branding in quite the way we saw the later 1990s. Yet, just as Thatcher had a part in laying the foundation for the contemporary practice of $\mathrm{PD}$, we must recall that PD had a role in laying the foundation for Margaret Thatcher.

At the beginning of her career Margaret Thatcher was, by her own account, profoundly shaped by public diplomacy: the public diplomacy of the United States. In 1967 she was a rising star of the Conservative opposition backbenches. Although getting noticed for her spirited forays on financial affairs, she had no experience in international matters and displayed no particular urgency to acquire any. Her approach to conservatism was patriotic and rather parochial. At this point the PD team at the US embassy selected her to receive a 6-week 'international visitor program' tour of the United States and meet persons of particular interest to her. Her visit included a meeting with White House adviser Walt Rostow and a visit to NASA's Mission Control in Houston. Looking back on the experience in the first volume of her memoirs in 1995 she commented: 'the excitement which I felt has never really subsided. At each stopover I was met and accommodated by friendly, open, generous people who took me into their homes and lives and showed me their cities and townships with evident pride' (Thatcher, 1995). It was a personal revelation and began a personal journey of ideological convergence between her take on British Conservatism and the rising tide of a re-invigorated American Conservatism. Her view of America certainly stood in contrast with that of her predecessor as leader of the Conservative Party, the Europhile Edward Heath, who had been an Atlantic sceptic since his own first visit to the United States as a student debater in 1938. In the 1970s, Thatcher would build an intellectual 
framework around the emotional skeleton of her pro-Americanism built in 1967 thanks to her 'guru' Keith Joseph, but the net result was that when the American incarnation of the swing to the right reached the White House in the form of Ronald Reagan its British equivalent was already in place and open to collaboration. It was a handsome pay-off for a tiny investment back in 1967 and one which US public diplomats have not been slow to trumpet in the years since. ${ }^{4}$

What then is the bottom line? That Thatcher shaped and was shaped by PD is a testament to the significance of both. That her death is in its own way PD - forming the image of Britain overseas as surely as last year's Diamond Jubilee or the London Olympics - is also undeniable. That her demise has been accompanied by a debate over her legacy does not diminish its contribution to Britain's image, in fact it serves to refine that image and remind the world that Britain remains a country in which people expect to have a say and people with the deepest distain for what was being said defend the people's right to say it. Hopefully Margaret Thatcher would have approved.

\section{NOTES}

1 Margaret Thatcher, speech to Finchley Conservative Party, 31 January 1976, archived at www.margaretthatcher.org/speeches/displaydocument.asp?docid $=102947$
2 For an example, see her criticism of the Greater London Council for honouring the imprisoned Nelson Mandela with a sculpture on London's South Bank in prime minister's questions, 29 October 1985, archived at www .margaretthatcher.org/document/106160. Her much quoted remark that 'the ANC is a typical terrorist organisation ... Anyone who thinks it's going to run the government in South Africa is living in cloud cuckoo land' is apocryphal though partially derived from remarks made in 1987 by her press secretary Bernard Ingham on the unlikelihood of an ANC military victory. For discussion see www.politicsweb.co.za/politicsweb/view/ politicsweb/en/page 71619 ?oid $=368740 \&$ sn $=$ Detail\&pid $=71619$

3 This file is reproduced at www.margarett hatcher.org/archive/arcdocs/791004_BB CExt.pdf.

4 For a detailed analysis of Thatcher's visit to the United States see Giles Scott-Smith (2003).

\section{REFERENCES}

Scott-Smith, G. (2003) Her rather ambitious Washington program: Margaret Thatcher's international visitor program visit to the United States in 1967. British Contemporary History 17(4): 65-86.

Thatcher, M. (1995) The Path to Power. New York: Harper Collins, pp. 153-154.

Nicholas J. Cull University of Southern California, Los Angeles, CA E-mail: cull@usc.edu 